Marianna Czapnik

Warszawa

\title{
Zasoby informacyjne CERL źródłem do badań nad europejskim dziedzictwem piśmienniczym
}

Konsorcjum Europejskich Bibliotek Naukowych (CERL) ${ }^{1}$ powstało jako odpowiedź na rosnącą liczbę bibliotek rozpoczynających tworzenie elektronicznych katalogów starych druków. Pojawiła się zatem konieczność nawiązania międzynarodowej współpracy w zakresie upowszechniania standardów opisu katalogowego i wypracowania wspólnych reguł udostępniania wiedzy o książce historycznej. Spotkanie przedstawicieli kilku europejskich bibliotek naukowych zaowocowało powołaniem w 1992 r. Consortium of European Reseach Libraries, formalnie zarejestrowanym w 1994 r. z siedzibą w Wielkiej Brytanii ${ }^{2}$. Podstawowym zadaniem (misją) CERL jest promocja europejskiego dziedzictwa rękopiśmiennego i drukowanego.

W skład Konsorcjum wchodzą, na zasadach partnerskich, członkowie pełnoprawni, stowarzyszeni i specjalni oraz grupy bibliotek ${ }^{3}$. Każda $\mathrm{z}$ tych kategorii ma określone prawa związane $\mathrm{z}$ uczestniczeniem $\mathrm{w}$ pracach Konsorcjum, zapisane w dokumencie Rules and Regulations. W skład CERL wchodzą obecnie 34 instytucje z krajów europejskich i USA, mające status Full Members. Stałymi członkami są m.in. biblioteki narodowe, Belgii, Chorwacji ${ }^{4}$, Danii, Finlandii, Francji, Hiszpanii, Holandii, Luksemburga, Niemiec, Norwegii, Szwecji, Szkocji i Rosji. Zamiar przystąpienia do CERL w 2012 r. zgłosiła książnica narodowa

${ }^{1}$ Zob. http://www.cerl.org/en/about/main [wszystkie dostępy 2 XI 2012].

${ }^{2}$ Więcej zob.: M. Czapnik, Konsorcjum Europejskich Bibliotek Naukowych i udziat w nim Biblioteki Uniwersyteckiej $w$ Warszawie, Przegl. Bibliot., 70:2002, z. 4, s. 295-303; W. Karlak, Dziatalność Consortium of European Research Libraries (CERL) $i$ udziat w nim polskich bibliotek, ,Roczniki Biblioteczne”, 53:2009, s. 301-311.

${ }^{3}$ Zob. http://www.cerl.org/en/membership/list_members

${ }^{4}$ Do końca 2012 r. 
Austrii ${ }^{5}$. Członkowie pełnoprawni mogą tworzyć tzw. klastry, czyli zespoły złożone z mniejszych bibliotek w swoim kraju lub regionie. W CERL ponadto zarejestrowano cztery grupy bibliotek: z Estonii, Polski, Belgii (Vlaamse Erfgoedbibliothek) oraz krajów Ameryki Środkowej i Południowej (ABINIA), obejmujące łącznie 25 książnic. W ostatnich latach, z powodu kryzysu finansowego, duży nacisk kładzie się na tworzenie grup, którym oferowane są specjalne warunki finansowe. Grupy mogą tworzyć biblioteki z różnych krajów, a liczba instytucji uczestniczących może się wahać od dwóch do szesnastu. Pełna opłata (8000 euro rocznie) jest wówczas dzielona równomiernie pomiędzy biblioteki członkowskie ${ }^{6}$. Grupa Polskich Bibliotek Naukowych Gromadzących Stare Druki zawiązała się pod koniec 2006 roku$^{7}$. Tworzą ją obecnie biblioteki: Narodowa, uniwersyteckie z Warszawy, Poznania i Wrocławia, Jagiellońska, Zakładu Narodowego im. Ossolińskich oraz Książnica Kopernikańska w Toruniu. Formalnie funkcję lidera pełni Biblioteka Narodowa.

CERL działa poprzez trzyosobowy zarząd oraz ciała wybieralne spośód osób reprezentujących biblioteki członkowskie - radę dyrektorów i komitet wykonawczy. Funkcje doradcze pełnią grupy robocze (Working Groups) powoływane do określonych zadań, do których mogą zgłosić się również specjaliści z instytucji nie będących członkami CERL. Tymi zadaniami są problemy związane $\mathrm{z}$ opracowaniem zabytkowych opraw, proweniencji inkunabułów i starych druków, udostępniania zasobów rękopiśmiennych, rozwoju katalogu HPB i tezaurusów CERL, rozwoju i promocji CERL, itd. ${ }^{8}$

Każdego roku, zazwyczaj w listopadzie, organizowane są konferencje i zebrania sprawozdawczo-wyborcze. Referaty wygłoszone na konferencji wydawane są drukiem w serii CERL Papers (nr I-XI), które bezpłat-

${ }^{5}$ Secretariat Report, 29 and 31 October 2012, The British Library. London, s. 1 [dostęp po zalogowaniu].

${ }^{6}$ Tamże, s. 2-3; opłata dla bibliotek tworzących grupę 16 lub więcej instytucji wynosi obecnie 500 euro rocznie, por. http://www.cerl.org/en/membership/group_membership

${ }^{7}$ M. Czapnik, Seminarium Polskiej Grupy CERL 14-15 I 2009 r., Przegl. Bibliot., 77:2009, z. 1, s. 103-107; R. Wilgosiewicz-Skutecka, Seminarium polskiej grupy CERL, Biuletyn EBIB, 2009, nr 3.

${ }^{8}$ Jest ich obecnie osiem: Book Bindings (Interest Group); Heritage of the Printed Book Database (HPB) (Project Group); Material Evidence in Incunabula (Project Group); CERL Portal (Project Group); Promoting of CERL's Activities and Services (Project and Strategy Group); Provenance and Standards for the description of Provenance Evidence (Interest Group); Strategy and Integration of Resources (Strategic Group), CERL Thesaurus (Project Group). Członkowie grup komunikują się ze sobą przez e-mail, skype oraz WebEx, natomiast spotkania Komitetu Wykonawczego (Executive Committee) odbywają się dwa razy do roku. 
nie otrzymują przedstawiciele bibliotek uczestniczących w dorocznym zebraniu ${ }^{9}$. Ponadto, w poszczególnych krajach organizowane są warsztaty tematyczne otwarte dla wszystkich zainteresowanych - w Polsce miały one miejsce w 2009 r. w Bibliotece Uniwersyteckiej w Warszawie. Aktualne informacje o CERL, katalogach i bazach elektronicznych, współpracy $\mathrm{z}$ innymi organizacjami oraz inicjatywach podejmowanych przez biblioteki członkowskie, ukazują się w dwa razy do roku w czasopiśmie elektronicznym CERL Newsletter ${ }^{10}$. Nie bez znaczenia są również wiadomości o różnych przedsięwzięciach i projektach badawczych nadsyłane pocztą elektroniczną z instytucji członkowskich. Jedną z najnowszych propozycji jest niemiecki portal wiedzy o książce, bibliotekach i informacji naukowej, tworzony w Bawarskiej Bibliotece Państwowej w Monachium (BSB), pod nazwą „b2i”11. CERL podejmuje także współpracę $\mathrm{z}$ innymi organizacjami i stowarzyszeniami bibliotekarskimi, m.in. z IFLA, LIBER, TEL i Europeaną.

\section{Heritage of the Printed Book Database (HPB $)^{12}$}

Jako podstawowe zadanie CERL przyjęto tworzenie katalogu, w którym zgromadzone zostaną opisy wszystkich publikacji wydanych w Europie w okresie książki wytwarzanej ręcznie (do ok.1830 r.). Jest to katalog katalogów łączący rekordy druków i innych dokumentów bibliotecznych, przesyłanych przez biblioteki członkowskie. Umożliwia równoczesne przeszukanie kilkudziesięciu katalogów lokalnych i zbiorczych. W przyjętych zasadach opisu katalogowego respektowane są tradycyjne, narodowe normy opracowania starych druków. Proces napełniania katalogu postępuje dość szybko, obecnie obejmuje już blisko 4,3 mln rekordów (wzrost w 2012 r. o ok. 775 tys.) nadesłanych przez biblioteki z 21 krajów $^{13}$. Należy przy tym pamiętać, że wiele rekordów

${ }^{9} \mathrm{Nr}$ I-III w wersji pełnotekstowej można pobrać ze strony CERL [http://www.cerl. org/en/publications/cerl_papers/main], tamże spisy treści; skany nr V-X są dostępne jedynie dla członków CERL.

${ }^{10}$ Zob. http://www.cerl.org/en/publications/newsletter

11 Zob. www.b2i.de

12 Poprzednia nazwa The Hand Press Book Database [http://www.cerl.org/en/resources/hpb/main - dostęp po zalogowaniu dla wszystkich czytelników bibliotek członkowskich].

${ }^{13}$ W HPB znajdują się opisy starych druków przesłane z bibliotek narodowych, uniwersyteckich i naukowych z Belgii, Chorwacji, Czech, Danii, Estonii, Finlandii, Francji, Hiszpanii, Holandii, Litwy, Łotwy, Niemiec, Polski, Rosji, Słowenii, Szwecji, Watykanu, Węgier, Wielkiej Brytanii, Włoch; instytutów bibliograficznych (ICCU, ABES) oraz książnicy Uniwersytetu Yale w New Haven (USA). Opisy starych druków ze zbiorów polskich dostarczyły biblioteki uniwersyteckie w Warszawie (3557) i Wrocławiu (1552), Bi- 
w HPB jest zdublowanych lub zwielokrotnionych, co oznacza, że otrzymamy kilka lub kilkanaście opisów jednego dzieła. Tę niedogodność do pewnego stopnia niweluje rozbudowany system funkcji wyszukiwawczych, który ułatwia uzyskanie pożądanej odpowiedzi. Przykładowo, wprowadzając kody kraju i języka możemy prześledzić, w których bibliotekach zagranicznych, i w jakiej ilości znajdują się druki polskie lub Polski dotyczące. Nie mniej ważnym narzędziem jest opcja kopiowania opisów wytworzonych w innych bibliotekach do własnych katalogów, a tym samym przyśpieszenia opracowania zbiorów lokalnych. W grudniu 2011 r. wprowadzono możliwość indeksowania danych o proweniencji i oprawie dzieła (pola 561, 563, 700 i 710 wg MARC21), otwierając w ten sposób drogę do szerszego niż dotychczas umieszczania w rekordzie danych dotyczących cech fizycznych egzemplarza ${ }^{14}$. Z początkiem 2013 r. HPB będzie przeniesiony i umieszczony na serwerach VZG/GBV (Verbund Zentrale des GBV) w Getyndze ${ }^{15}$. Aktualnym „gospodarzem" (do kwietnia 2013 r.) jest OCLC (Online Computer Library Center) w USA.

\section{CERL Thesaurus and Digital Resources $(\mathrm{CT})^{16}$}

Dostępny bezpłatnie słownik terminów ujednoliconych i odrzuconych, wspomagający przeszukiwanie katalogu HPB i kartotek elektronicznych Konsorcjum, zawiera rekordy nazw osobowych i korporatywnych, drukarzy i oficyn drukarskich, miejsc druku oraz cytowanej literatury. Dane te przejmowane są z kartotek haseł autorytatywnych przesyłanych w większości przez biblioteki członkowskie ${ }^{17}$. W napełnianiu tezaurusów mogą uczestniczyć również biblioteki i instytucje nie należące do CERL. Inaczej niż to przyjęto w założeniach katalogu HPB, administratorzy omawianej bazy starają się łączyć rekordy zdublowane, zacho-

blioteka Narodowa (1345), Jagiellońska (ok. 15000 - przewidziane do włączenia na pocz. 2013 r.). Ponadto do HPB włączono opisy mikrofilmów druków XVI-XVIII w. wydanych na terenach Śląska, Prus Wschodnich i Pomorza, sporządzonych w ramach tzw. projektu Boscha (ok. 35 tys. rekordów pod nazwą „16 $16^{\text {th }}-18^{\text {th }}$ Century Prints, Poland”), z Bibliotek: Narodowej, Uniwersyteckiej we Wrocławiu, PAN w Gdańsku oraz Książnicy Pomorskiej w Szczecinie. W stosunku do zasobów starodrucznych zgromadzonych w polskich książnicach, wciąż jest to niestety nikły procent.

${ }^{14}$ Więcej zob. http://www.oclc.org/support/documentation/worldcat/tb/260/, zob. też http://www.cerl.org/en/resources/provenance/marc

15 Zob. https://www.gbv.de

${ }_{16}$ Zob. http://thesaurus.cerl.org/cgi-bin/search.pl

17 Zob. http://www.cerl.org/en/resources/cerl_thesaurus/contents; dane statystyczne zob. http://www.cerl.org/en/resources/cerl_thesaurus/statistics 
wując nazwy i adnotacje w języku twórców hasła. Słowniki obsługują linki wewnętrzne, przez rekordy powiązane (Related records) łączą miejsca druku z nazwami drukarzy, autorami i instytucjami działającymi w danej miejscowości, a także rekordami właścicieli ksiąg i księgozbiorów. CT ułatwia dotarcie do innych zewnętrznych zasobów dostępnych online, takich jak bazy proweniencyjne, sygnetów drukarskich oraz znaków wodnych. Interesującym uzupełnieniem nazw miejsc druku są dołączone do rekordu mapy danego regionu, pobierane $\mathrm{z}$ bazy Bernstein Paper Atlas. Obecnie trwają prace nad nowym interfejsem, w którym będzie można przeszukiwać duże bazy zewnętrzne (Europeana, EROMM Web Search, TEL ${ }^{18}$ ) używając terminów z rekordów znajdujących się w słownikach CERL. Tezaurusy cieszą się dużym zainteresowaniem środowiska naukowego w wielu krajach. Systematycznie oferowane są nowe kartoteki do włączenia do CT. Przykładowo, Biblioteka Narodowa Szkocji udostępniła ostatnio 200 rekordów zawierających nazwy drukarzy i oficyn drukarskich wraz z dostępem do skanów sygnetów drukarskich oraz pełnotekstowych wersji druków ${ }^{19}$. Natomiast Włosi oferują kartotekę zawierającą opisy 6115 instytucji religijnych zintegrowane z bazą Research of the Inquiry of the Congregation of the Index (RICI), w ktorej umieszczono dokumentację dotyczącą wprowadzania Indeksu Ksiąg Zakazanych we włoskich klasztorach i instytucjach kościelnych ${ }^{20}$. Tezaurusy CERL obecnie liczą ok. 918 tys. rekordów (w tym ok. 15 tys. hasel proweniencyjnych - stan na 26 X 2012). Ponad 99\% rekordów jest indeksowanych przez Google. Polskie zasoby reprezentowane są dotychczas przez rekordy przekazane z bibliotek uniwersyteckich w Warszawie (nazwy osobowe i korporatywne oraz tytułów ujednoliconych) i Wrocławiu (nazwy osobowe i korporatywne oraz nazwy drukarzy). Hasła autorytatywne przesłane przez Bibliotekę Narodową i Jagiellońską oczekują na włączenie. Biblioteka Uniwersytecka w Warszawie dodatkowo w 2009 r. przekazała do CERL 3282 adnotowanych haseł proweniencyjnych, osobowych i korporatywnych ${ }^{21}$.

${ }^{18}$ Zob. np. projekt, pod nazwą Europeana Regia, udostępniania rozproszonych rękopisów ze zbiorów królewskich (the Biblioteca Carolina, the Library of Charles V and Family, the Library of Aragonese Kings of Naples) - http://www.europeanaregia.eu

${ }^{19}$ Zob. The Spread of Scottisch Printing [http://digital.nls.uk/printing/]

${ }^{20}$ CERL Newsletter, 2012, no. 25 s. 2 [http://www.cerl.org/en/publications/newsletter]

${ }^{21}$ Użytkownik odsyłany jest do katalogu drukowanego, Katalog druków XVI w. w zbiorach Biblioteki Uniwersyteckiej w Warszawie, t. 1-3, Warszawa 1994-2007. 


\section{CERL Portal for Manuscripts and Early Printed Material ${ }^{22}$}

CERL Portal służy do wyszukiwania materiałów bibliotecznych i archiwalnych (rękopiśmiennych i drukowanych) oraz dokumentów wtórnych. Zapewnia zintegrowany dostęp do katalogów elektronicznych i baz pełnotekstowych rękopisów i archiwaliów niezależnie od okresu ich wytworzenia, przechowywanych w wielu bibliotekach europejskich, USA i Australii. Początkowo zaprojektowany jedynie dla upowszechniania informacji o materiałach rękopiśmiennych, obecnie pozwala również na przeszukiwanie katalogów druków wydanych przed 1830 r., w tym tych, które dotychczas z różnych powodów pozostają poza HPB. Są to katalogi druków angielskich i anglojęzycznych (ESTC), publikacji niemieckich z XVII w. (VD17), centralnego katalogu hiszpańskiego dziedzictwa rękopiśmiennego i drukowanego (CCBP) oraz czeskiego Manuscriptorium. Oprócz tego udostępniono bazę EROMM rejestrującą dokumenty wtórne (ok. 9 mln opisów mikrofilmów, mikrofisz i dokumentów cyfrowych). Dodatkowo za pośrednictwem tego portalu można bezpłatnie korzystać z katalogu HPB, z tym ograniczeniem, że w odpowiedzi otrzymujemy jedynie prymarny opis poszukiwanego dzieła (autor, tytuł, rok wydania), bez informacji o miejscu przechowywania. CERL Portal jest dostępny bez ograniczeń, również dla krajów i placówek nie należących do Konsorcjum. Tworzony jest przez biblioteki i instytucje, które są zainteresowane promocją i udostępnieniem swoich zasobów rękopiśmiennych i drukowanych szerokim kręgom użytkowników na całym świecie.

\section{Provenance Information ${ }^{23}$}

Strona przeznaczona jest dla użytkowników zainteresowanych przede wszystkim badaniami proweniencyjnymi książek zabytkowych i rękopisów. Zamieszczane są tam informacje o bazach wewnętrznych $\mathrm{CERL}^{24}$ oraz adresy internetowe do zasobów zewnętrznych. Poszukiwania dawnych właścicieli można przeprowadzić w trzech zintegrowanych bazach elektronicznych. Rekordy zawierające nazwy osobowe i korporatywne, przesyłane przez różne zespoły badawcze, włączane są do CERL

22 Zob. http://cerl.epc.ub.uu.se/sportal/

${ }^{23}$ Zob. http://www.cerl.org/web/en/resources/provenance/main

${ }^{24} \mathrm{~Np}$. Index Possessorum Incunabulorum oprac. przez Paula Needhama - http://ipi. cerl.org/cgi-bin/search.pl?start $=$ true 
Thesaurus $^{25}$. Nazwy właścicieli, przejmowane z lokalnych kartotek haseł autorytatywnych odsyłają nas do rekordu w katalogu elektronicznym biblioteki przechowującej opisywany egzemplarz. Narzędzie „Can You Help - Indentifying Provenance Evidence" umożliwia publiczną dyskusję dotyczącą identyfikacji nieznanych bądź nierozpoznanych znaków proweniencyjnych ${ }^{26}$. Trzecia $z$ tych baz, Material Evidence in Incunabula zostanie omówiona w odrębnym akapicie. Na stronie Provenance Information udostępniane są ponadto informacje o projektach badawczych i publikacjach z zakresu wiedzy o dawnej książce i księgozbiorach historycznych, a także wyniki badań proweniencyjnych i oprawoznawczych, w podziale na poszczególne kraje ${ }^{27}$. Zgromadzone już zasoby informacyjne obejmują linki do tekstów zdigitalizowanych, noty o publikacjach dotyczących badań proweniencyjnych i tegumenologicznch, katalogach zawierających wykazy dawnych właścicieli, itp. Ponadto, znajdują się tu informacje i linki do spisów dawnych właścicieli, baz znaków i zapisów proweniencyjnych oraz zabytkowych opraw tworzonych w różnych środowiskach naukowych. Jedną z ciekawszych realizacji takich projektów jest francuska baza proweniencyjna, „Base Provenance des livres anciens" biblioteki miejskiej w Lyonie ${ }^{28}$. Zawiera ilustracje superekslibrisów, tłoczeń, ekslibrisów, pieczęci i zapisów własnościowych dawnych posesorów wraz z towarzyszącą im informacją o właścicielu i jego księgozbiorze. Inne biblioteki, których zasoby proweniencyjne widoczne są w katalogach i bazach CERL, informacje o dawnych właścicielach i oprawach uwzględniają w opisie bibliograficznym. Polskę reprezentuje jedynie baza opraw tworzona w Bibliotece Poznańskiego Towarzystwa Przyjaciół Nauk ${ }^{29}$. Do zamieszczania informacji o katalogach, książkach, artykułach, bazach internetowych oraz innych projektach dotyczących badań proweniencyjnych, zapraszani są bibliotekarze i badacze ze wszystkich środowisk naukowych ${ }^{30}$.

${ }^{25}$ Zob. wykaz bibliotek - http://www.cerl.org/en/resources/provenance/cerl_thesaurus

${ }^{26}$ Zob. http://www.cerl.org/en/resources/provenance/can_you_help

${ }_{27}$ Zob. http://www.cerl.org/en/resources/provenance/geographical

${ }_{28}$ Zob. http://www.bm-lyon.fr/trouver/basesdedonnees/base_provenance.htm, zob też R. Wilgosiewicz-Skutecka, Lyońska baza proweniencji - poznańskie marzenia, „Biblioteka" nr 10 19: 2006, s. 201-207.

${ }^{29}$ Zob. http://www.cerl.org/en/resources/provenance/geographical\#poland

${ }^{30}$ Więcej zob. na stronie http://www.cerl.org/en/resources/provenance/contribute 


\section{Material Evidence in Incunabula (MEI) $)^{31}$}

MEI jest najmłodszym projektem CERL, który powstał przy współpracy $\mathrm{z}$ uniwersytetem w Oksfordzie, British Library oraz kilku bibliotek włoskich. Systematycznie dołączają obecnie inne książnice, z Londynu, Madrytu, Barcelony, Petersburga i Stanów Zjednoczonych ${ }^{32}$. Powstająca baza przeznaczona jest do rejestracji cech fizycznych druków XV w., takich jak: zapisy proweniencyjne, znaki własnościowe (pieczęcie, ekslibrisy, superekslibrisy, itp.), marginalia i innego rodzaju noty rękopiśmienne, informacja o oprawie, itp. Opisy bibliograficzne inkunabułów pobierane są z katalogu Incunabula Short Title Catalogue (ISTC) ${ }^{33}$ prowadzonego w British Library, natomiast ujednolicone nazwy posesorów z CERL Thesaurus. Taka kombinacja daje możliwość poznania danych bibliograficznych inkunabułu w połączeniu $\mathrm{z}$ opisem cech konkretnego egzemplarza. Poprzedni właściciele są szeregowani według określonych kategorii: osoby prywatne lub instytucje, duchowne lub świeckie, kobiety, mężczyźni oraz według profesji. Ponadto, indeksowane są zapisy rękopiśmienne, np. noty korektorskie, tłumaczenia, komentarze do tekstu, cena i miejsce zakupu, cenzura, podkreślenia, inne ślady lektury, itp. Zapisy proweniencyjne są odnotowywane w formie występującej na druku. Zgromadzony materiał posłuży do wieloaspektowych badań nad książką historyczną. Specjaliści z innych krajów są zachęcani do wprowadzania do MEI swoich danych ${ }^{34}$. Korzystanie z bazy jest nieodpłatne. Obsługa projektu, w tym również związana $\mathrm{z}$ rozwojem interfejsu, jest finansowana z grantów zewnętrznych.

\section{Web Resources for the History of the Book ${ }^{35}$}

Na tej stronie zamieszczane są linki do zasobów internetowych, dotyczących wszelkich aspektów badań nad dawną książką rękopiśmienną i drukowaną oraz do instytucji zajmujących się tymi zagadnieniami.

${ }^{31}$ Zob. http://www.cerl.org/en/resources/mei/main

${ }^{32}$ Material Evidence in Incunabula (MEI): an update, [w:] CERL Newsletter, No. 25, 2012 s. 4 [Dokument elektroniczny] http://www.cerl.org/en/publications/newsletter

33 ISTC [http://www.bl.uk/catalogues/istc/] jest międzynarodową bazą, tworzoną w British Library w Londynie, przy współpracy osób i instytucji z całego świata. Zawiera obecnie 29777 edycji druków wydanych do 1501 r., z wykazem bibliotek przechowujących daną pozycję.

${ }^{34}$ Zasady wprowadzania danych i format opisu, zob. http://www.cerl.org/en/help/incunabula/main\#editing

${ }^{35}$ Zob. http://www.cerl.org/en/resources/links_to_other_resources/main 
Adresy internetowe są pogrupowane według następujących kategorii: katalogi biblioteczne i antykwaryczne, standardy opisów bibliograficznych (MARC 21, UNIMARC, PICA, itd.), bazy online sygnetów drukarskich i znaków wodnych, historia książki, muzea, placówki badawcze, stowarzyszenia i organizacje bibliotekarskie (CILIB, CURL, IFLA, LIBER, OCLC, itd). Próżno tam jednak szukać linku chociażby do katalogu NUKAT czy elektronicznej wersji Bibliografii Polskiej Estreicherów.

\section{Podsumowanie}

Konsorcjum Europejskich Bibliotek Naukowych umożliwia dyskusję i wymianę doświadczeń bibliotekarzy z wielu znaczących książnic europejskich i specjalistów z różnych środowisk naukowych również spoza Starego Kontynentu. Powstanie katalogu HPB i innych kartotek elektronicznych w sposób istotny zwiększa efektywność bibliograficznych i historycznych badań nad książką rękopiśmienną i drukowaną. Nie byłoby to jednak realne do osiągnięcia bez dużego zaangażowania bibliotekarzy i specjalistów reprezentujących poszczególne kraje. Oczekiwania CERL wobec bibliotekarzy i historyków książki w Polsce, wyartykułowane na seminarium w 2009 r. pozostają wciąż aktualne, a są nimi: uzupełnianie katalogu HPB o opisy bibliograficzne starych druków z krajowych repozytoriów (mogą je przesyłać biblioteki nie należące do CERL), przesyłanie do CERL Thesaurus rekordów miejsc druku, drukarzy i oficyn wydawniczych działających w Polsce, a także nazw właścicieli księgozbiorów. Nie mniej istotne jest uzupełnianie strony Provenance Information o materiały dotyczące badań nad polskim dziedzictwem piśmienniczym.

CERL może być dla krajowych bibliotekarzy i badaczy źródłem informacji, pomocą przy opracowaniu lokalnych zbiorów, repozytorium własnych danych (których w HPB wciąż jest niewiele), a także inspiracją dla rodzimych projektów. Bazy sygnetów drukarskich i znaków proweniencyjnych uwidocznione na stronie CERL, mogą posłużyć jako wzór dla podobnych kartotek tworzonych przez krajowe zespoły.

W Polsce brak jest obecnie jakiegokolwiek centralnego ośrodka badań nad dawną książką. Powołanie Polskiej Grupy CERL niczego w tym zakresie nie zmieniło. Rola Biblioteki Narodowej, która zgodziła się pełnić funkcję lidera, jest w tym względzie czysto formalna. Brak chociażby cyklicznych spotkań bibliotek członkowskich. Pomimo prób podejmowanych przez środowisko starodruczników (warsztaty w Poznaniu 
w $2010 \mathrm{r}^{36}$ ), nie udało się dotychczas rozpocząć żadnych ogólnokrajowych projektów w zakresie badań nad książką zabytkową i tworzenia elektronicznych baz właścicieli księgozbiorów.

Znajomość zasobów informacyjnych CERL w Polsce jest nadal niewystarczająca, zwłaszcza w środowisku uczelni wyższych. Często są również nieprecyzyjne powtarzane informacje dotyczące dostępności baz CERL dla użytkowników z instytucji nie należących do tej organizacji. Chciałabym ponownie podkreślić, że płatny i wymagający logowania jest jedynie dostęp do pełnej zawartości katalogu HPB. W wersji prymarnej ten katalog jest udostępniany bezpłatnie na stronie CERL Portal, o czym już wspominano. Pozostałe bazy elektroniczne Konsorcjum zawsze były i są udostępniane bez żadnych ograniczeń wszystkim zainteresowanym. Trwa dyskusja, także na tegorocznym zebraniu CERL w Londynie, nad wprowadzeniem Open Access do pełnej wersji HPB.

${ }^{36}$ Zob. notatkę I. Wiencek w Biuletynie BUW, s. 6-7 [http://www.buw.uw.edu.pl/images/BUW_PDF/ Biuletyn_BUW/wrzesien2010.pdf]; zob. też H. Mieczkowska, Katalogowanie starych druków w närodowym uniwersalnym katalogu centralnym (NUKAT), „Roczniki Biblioteczne", 53:2009 s. 205-221. 